\title{
ИЗВЕСТНЫЙ И НЕИЗВЕСТНЫЙ АЛЕКСАНДР НЕВСКИЙ - ЗАЩИТНИК И СПАСИТЕЛЬ РУССКОГО НАРОДА (К 800-ЛЕТИЮ СО ДНЯ РОЖДЕНИЯ)
}

Мехонцева Валерия Андреевна Сердитова Анастасия Алексеевна Искандарова Сарвиноз Ойбек-кизи студенты Научный руководитель: Ильина Елена Ивановна Медицинский колледж УрГУПС

Аннотация: Александр Невский в памяти народа и истории ассоциируется как защитник Отечества и талантливый полководец, храбрый воин. Он заложил принципы политики и сохранил православие.

Ключевые слова: Государственный и политический деятель, полководец, правитель, монголо-татары, крестоносцы, принципы политики.

\section{FAMOUS AND UNKNOWN ALEXANDER NEVSKY - DEFENDER AND SAVIOR OF THE RUSSIAN PEOPLE (ON THE 800TH ANNIVERSARY OF HIS BIRTH)}

Mekhontseva Valeria Andreevna Serditova Anastasia Alekseevna Iskandarova Sarvinoz Oybek-kizi students Scientific supervisor: Ilina Elena Ivanovna USUPS Medical College

\footnotetext{
Abstract: Alexander Nevsky is associated in the memory of the people and history as a defender of the Fatherland and a talented commander, a brave warrior. He laid down the principles of politics and preserved Orthodoxy.

Key words: Statesman and politician, commander, ruler, Mongol-Tatars, crusaders, principles of politics.

Александр Ярославич Невский (1220 или 1221-1263), второй сын новгородского, киевского и владимирского князя Ярослава родившейся в 


\section{НАУКА И ОБРАЗОВАНИЕ В КОНТЕКСТЕ

непростое время - 13 век в истории Руси период феодальной раздробленности: борьбы за владения землями и власти в государстве, сопровождающейся агрессией с Запада и Востока.

На протяжении всей истории Российского государства деятельность Александра Невского как политика, правителя и полководца вызывает пристальное внимание - не только с точки зрения успешности проведения сражений и сохранения духовного единства раздробившегося государства, но и принятием неординарных мер, методов, стратегических решений.

Князь Александр Ярославич в 2008 году всенародным голосованием провозглашен «именем России» потому, что как полководец он не проиграл ни одной битвы крестоносцам и как дипломат - заключивший шаткий, но мир с наиболее опасным врагом - монголо-татарами. Александр внук Всеволода Большое Гнездо отразил нападение с Запада, защитил православие, от католической экспансии сохранив стержень государственности и духовного единства русского народа, он ставил интересы народа в приоритет княжеским.

Bce поколения нашей страны воспитаны на примере патриотизма, преданности, сохраняя генетическую память и веру в непобедимости русского народа перед завоевателями. Орденом Александра Невского награждают российских военачальников. Он был учрежден еще Екатериной I и возрожден в 1942 году в СССР, в 1992 году вошел в число главных государственных наград новой России.

Правление Александра Невского спасло Русь как государственное образование и является образцом деятельности в политике последующих руководителей: когда применять меч против опасных врагов, а когда умение выстраивать гибкую политику по отношению более могущественному противнику, порой в ущерб своей репутации в глазах соотечественников. «Основывая новую столицу на устье многоводной реки, для блага русскому государству, Пётр Великий обращал свой взор к далекому прошлому Родины и в подвигах святаго Александра Невского, доблестного стража и небеснаго покровителя Русской земли у берегов Невы, находил для себя опору и благословение», - написано в книге «Святой благоверный великий князь Александр Невский и Свято-Троицкая Александро-Невская лавра: на память двухсотлетия обители» (1913).

В исторической памяти народа Александр Невский ассоциируется, прежде всего, как защитник Отечества и талантливый полководец, храбрый воин. Эти качества бесценны для правителя страны особенно при 


\section{НАУКА И ОБРАЗОВАНИЕ В КОНТЕКСТЕ

одновременном натиске врагов, как с Востока превосходящего по численности войско в несколько раз русские дружины.

Вопрос о численности монгольского войска во время похода на Русь является одним из наименее спорных вопросов истории. Единственно в чем сходились исследователи - в признании огромной численности полчищ Батыя, обрушившихся на Русь.

Историки дореволюционного периода считают, что армии Батыя была в 300 тысяч воинов и их союзники и покоренные народы составляли 134тысячное войско, то есть около полумиллионное войско, жаждая наживы, обрушилось на разрозненные княжества Руси. В летописях ограничиваются указанием, что монголы наступали «в силе тяжце», «бесчислена множество, яко прузи траву поедающе» [1, с. 127]. Примерно так же говорят о войске Батыя и армянские источники. Записки европейцев - современников нашествия дают совершенно фантастические цифры. Плано Карпини, например, определяет численность войска Батыя, осаждавшего Киев, в 600 тыс. человек; венгерский летописец Симон утверждает, что в Венгрию с Батыем вторглось «500 тысяч вооруженных» [7].

Стоит в большой степени довериться свидетельствам персидского историка Рашид-ад-Дина, близкого к монгольской ставке и имевшего доступ к документам монгольской императорской канцелярии.

Он описывает, что Чингиз-ханом распределил между «сыновьями, братьями и племянниками» монгольское войско в «сто двадцать девять тысяч человек». В походе Батыя на Русь, по свидетельствам Рашид-ад-Дина и Джувейни, участвовали следующие царевичи-чингизиды: Бату, Бури, Орда, Шибан, Тангут, Кадан, Кулькан, Монкэ, Бюджик, Байдар, Менгу, Бучек и Гуюк. Подробный перечень монгольских войск, разделение их по тысячам и даже сотням, с указанием имен и родословных военачальников, список наследников и степень их родства с великим ханом, - все это свидетельствует о документальном характере сведений Рашид-ад-Дина. Эти свидетельство подтверждается и монгольской феодальной хроникой XIII в. Таким образом, эти сведения можно считать достоверными.

Исходя из этого соотношения общую численность войска Батыя накануне нашествия можно весьма приблизительно определить в 120-140 тысяч воинов.

В XIII в. войско монголо-татар в несколько тысяч человек представляло значительную силу, объединенная единым командованием, обладавшая хорошими боевыми качествами и опытом военных действий, маневренностью 


\section{НАУКА И ОБРАЗОВАНИЕ В КОНТЕКСТЕ

за счет коней, приходящихся по 2 и более на каждого воина Батыя, обязательной разведкой и применением тактики, которая заключалась в стремительности нанести внезапные удары по захваченному врасплох противнику, дезорганизовать, разобщить его ряды, прибегая для этого как к чисто военным, так и к дипломатическим средствам. Монголы по возможности избегали больших фронтальных сражений, разбивая противника по частям, изматывая его непрерывными стычками и внезапными нападениями. Также превосходство обеспечивалось применением заимствованного вооружения тараны, метательные машины, «греческий огонь» и т.д. Многочисленные китайские и персидские инженеры, постоянно находились в монгольской армии и обеспечивали завоевателей необходимым количеством осадных машин.

Стремясь, в первую очередь уничтожить живую силу противника и лишить возможности его пополнять войско, монголы проникали в глубь страны и опустошали все на своем пути - истребляя жителей и угоняя стада.

Разведка осуществлялась самыми различными методами военные походы, послы и купцы, проникающие в русские земли задолго до начала войны. В результате монголы прекрасно представляли положение дел в русских княжествах.

Русские летописи не содержат цифр общей численности русских войск накануне нашествия монголов. Историки могут только предполагать, что Северная Русь могла выставить в случае военной опасности около 50 тысяч воинов и примерно столько же могла выставить земли Южной Руси, т. е. всего около 100 тысяч воинов.

Но главным фактором, обусловившим слабость Руси, была феодальная раздробленность и разбросанные по обширным территориям и не связанные друг с другом города и княжества, что позволило отрядам Батыя по частям разбивать русских князей, и обеспечила монголам подавляющее превосходство над феодальными ополчениями и немногочисленными дружинами русских.

При этом русские города еще не накопили опыта борьбы с активной осадой и соответственно не были созданы специальные системы укреплений, способные противостоять штурму с массовым применением осадной техники.

Длительное и упорное сопротивление княжеств нашествию Батыя можно объяснить только огромным героизмом русского народа, любовью к Родине горожан и крестьян.

Одновременно с Запада превосходящие не только по численности, но и техническому оснащению двинулись войска крестоносцев. Возникает угроза 
полного уничтожения всего русского - народа, православия, самобытности, культуры и растворение в народах Европы и Азии.

Победы Александра Ярославича в 1240 году на Неве над рыцарями благодаря внезапному удару отбила желание у шведов направить новые силы на завоевание Новгородских земель. Но действия князя Ярославича не все жители Новгорода одобрили. Народ по достоинству оценил значение победы наградив Александра титулом Храбрый и позднее Невский.

В 1242 году новая угроза с Запада - немецкие рыцари двинулись на Новгородские земли. Не смотря на конфликт из-за разгрома шведов, князь Александр сумел объединить силы дружины и ополчений северных городов, используя знания о тактике ведения боя тевтонскими рыцарями и особенности их оснащения для достижения победы и предотвращении экспансии русских земель.

Данные победы спасли православие и остановили распространение католицизма на русские земли. И в дальнейшем религия помогла не только сохранить самобытность народа Руси, но и сплотить, объединить в единое государство.

Деятельностью во внешней политики и дипломатические продуманные шаги Александра Ярославича помогли сохранить русскую народность и тем самым обеспечила ее политическое будущее.

Историк Лев Гумилёв дает оценку дипломатическим действиям, считая князя Невского архитектором русско-ордынского альянса. Что благодаря братанию в 1251 году «Александр приехал в орду Батыя, подружился, а потом с его сыном Сартаком, вследствие чего стал сыном хана и в 1252 году привёл на Русь татарский корпус с опытным нойоном Неврюем»[6]. С точки зрения Гумилёва и его последователей, дружеские отношения Александра с Батыем, чьим уважением он пользовался, его сыном Сартаком и преемником - ханом Берке позволили наладить с Ордой возможно более мирные отношения, что способствовало синтезу восточнославянской и монголо-татарской культур и спасение Руси от разорительных набегов монголов. При этом на Руси многие внука Всеволода Большое Гнездо считают союзником монголов, а значит предателем интересов Руси и памяти героизма русского народа противостоящего Орде.

Но исторический анализ источников и событий помогает сделать вывод о дальновидности политических решений князя Александра Ярославича. И по сути он сформировал принципы ведения внешней политики в суровых 


\section{НАУКА И ОБРАЗОВАНИЕ В КОНТЕКСТЕ

условиях выживания и выбором между потерять не только государственный, но и духовный суверенитет, утратив православную веру и принять католицизм. Или подчинится языческим традициям Восток, пройдя кровный обряд и став «сыном» хана Батыя и тем самым Александр Невский спас не только православие, он спас и русский этнос и сохранил его для будущего

Великий князь Александр Невский в основу своей политики ставил принцип - сбережение людей. Он не давал повода монголам осуществлять набеги. Выкупал русских пленников из Орды. А значит, спасал попавших в беду людей. Он снял дань кровью, что значит, русские в качестве союзников служили в монгольском войске. Князь Невский во время пребывания в Орде смог убедить хана отказаться от русской дани кровью. Это важная победа в политике и первый шаг к спасению Руси, как военной державы.

Но особенно важным принципом нужно считать, что он никогда не поднимал руку на своих князей. Угрозы применения силы были, если они не подчинялись. Но междоусобных войн не вел.

Обеспечение тыла - еще один из принцип Александра Невского, необходимо иметь прочных союзников. А такими союзниками на последнем этапе его жизни стали литовцы. Он вел также переговоры с норвежцами против шведов, но не особо на них полагаясь. Российский министр иностранных дел Сергей Лавров считает, что Александр Невский заложил основы многовекторной политики.

Географическое положение Руси заставляет руководителей государства использовать, как дипломатические приемы для защиты интересов своего народа, так и быть готовыми к отражению нападений со стороны чаще всего «цивилизованного» Запада угрожающего независимости нашего народа. Политические принципы, сформированные князем Александром Ярославичем против врагов, которые покушаются на душу, на вечность, являются менталитетом русского народа и братских народов, входящих в состав России.

\section{Список литературы}

1. Д.В. Чернышевский "Приидоша бесчислены, яко прузи" Вопросы истории № 2, 1989, стр. 127-132

2. https://mgimo.ru/about/news/experts/156641/

3. https://livingheritage.ru/brand/gorod-sankt-peterburg/aleksandr-nevskij 
4. https://russkiymir.ru/publications/288115/

5. https://mihalchuk-1974.livejournal.com/256856.html

6. http://istlyap.ru/aleksandr-nevskij-byl-pobratimom-syna-batyya-sartaka/

7. https://stoyer.ru/vtorzhenie-tataro-mongolov-na-rus-zavoevanie-rusimongolo--/

(C) В.А. Мехонцева, А.А. Сердитова, С.О. Искандарова, 2022 